\title{
Om at oversætte fra arabisk
}

\section{Oversætterens tilgang til arbejdet og stoffet}

Lad det være sagt fra begyndelsen: Jeg er ikke oversætter, ikke professionel oversætter i hvert fald, i den forstand, at jeg har levet af - eller prøvet at leve af - at oversætte. Og når jeg ser tilbage på, hvad jeg har oversat gennem årene, er resultatet magert: To romaner, en halv snes noveller, et par digte, koran og lidt hadith. Men jeg skal gerne øse ud af mine få erfaringer og ved samme lejlighed selv få præciseret, hvor skoen trykker. For det gør den. Selv den simpleste arabiske sætning gør knuder, og længere sekvenser kan forekomme umulige at fordanske; det vil som regel være nødvendigt at bryde den syntaktiske struktur ned i den arabiske tekst og bygge den op igen fra grunden i den danske.

I det følgende vil jeg referere til to korte tekster, to kapitler i en roman, Blod af Sten, som jeg er ved at oversætte, og som - inshallah - vil blive publiceret engang i efteråret og dermed være min tredje oversatte roman. ${ }^{\mathrm{I}}$ De to tekster er arbejdsmateriale og ikke finpudsede. Forfatteren, Ibrahim al-Koni (f. 1948), er opvokset i en tuaregstamme i den libyske ørken og har fået sin uddannelse i litteratur ved Gorkiinstituttet i Moskva. Blod af Sten er hans første roman, afsluttet i Moskva 1989, og siden har han arbejdet sig op på over 5.000 sider skønlitteratur, romaner, novellesamlinger og aforismesamlinger.

Gængse oversættelsesproblematikker vil jeg ikke komme nærmere ind på, blot nævne, at jeg aldrig har været i Libyen, aldrig rejst gennem sand- og bjergørkenen eller fulgt en wadi med fare for liv og lemmer. ${ }^{2}$ Geografisk er afstanden stor mellem Amager og den libyske ørken. Men det er den sådan set også mellem Amager og en norsk bygd. Handlingen i romanen er nogenlunde nutidig; kaptajn Bordello og den italienske invasion af Abessinien kan tidsfæstes til 1935, og på det tidspunkt var romanens hovedperson en knøs på 18-20 år. Vi følger ham i episoder gennem hele livet frem til hans død som en gammel mand, omkring 1975? Denne påståede næsten-nutidighed (mine forældres generation ...) er ikke til at fatte, for kulturen, herunder tro og overtro, er så helt anderledes. Der er en tidsmæssig og kulturel afstand mellem et materialistisk forstadskvarter på Amager i 2009 og et nomadeliv med bøn 
og amuletter i hulerne i det sydlige Libyen i de første tre fjerdedele af det 20. århundrede. Men, igen, det er der sådan set også mellem dagens Amager og en missionsk bygd i Norge i begyndelsen af 1900-tallet.

Hvordan geografiske og tidsmæssige afstande påvirker sprogbrugen, om man skal lade sig påvirke af afsender eller modtager, det er forhold, der ikke betyder ret meget for oversættelse fra arabisk til dansk - eller til et hvilket som helst andet sprog. For dannet, litterært arabisk skriftsprog har stort set ikke ændret sig de sidste 1500 år. al-Koni skriver det smukkeste klassisk arabisk, selv i hovedpersonens, den illiterate, tuaregisktalende gedehyrdes replikker. Kun ganske få steder i bogen er dialekten stereotypt markeret som indikator på, at den, der udtaler replikken, ikke ejer hjertets dannelse. Jeg vil, som sagt, ikke bevæge mig ind på, om man bør respektere denne stagnation af det arabiske skriftsprog eller ej.

De specifikt arabiske oversættelsesproblematikker har jeg valgt at dele op i to afsnit. Det første afsnit omhandler nogle af det arabiske sprogs grammatiske ejendommeligheder - og jeg er bevidst om, at disse kan være kedsommelige og temmelig irrelevante for ikke-arabiskkyndige; men trods alt er det dér, skoen trykker mest og hele tiden, så jeg kan ikke forbigå dem. Desuden nærer jeg det lønlige håb, at en og anden alligevel vil finde sprogdelen interessant, for kendskab til et fremmedartet sprogs opbygning er trods alt adgangstegn til forståelse af den fremmedartede kultur. Andet afsnit beskæftiger sig med nogle få, men væsentlige aspekter inden for kultur og æstetik.

De to korte tekster, der tjener som eksempelmateriale for min redegørelse, bærer kapiteloverskrifterne Fra asken og i ilden og Slægtninges kød. Begge tekster er trykt i dette nummer af Passage, og det anbefales, at man læser teksterne inden artiklen. I det følgende er ordrette oversættelser samt mulige, men forkastede oversættelser forsynet med ufordoblede anførselstegn, '...', mens den oversættelse, der er trykt i Passage, og den foreløbigt endelige er forsynet med fordoblede anførselstegn, “...”. Alle sidehenvisninger refererer til oversættelsen i dette nummer af Passage.

\section{Sprog}

Litterært arabisk jonglerer med et overdådigt ordforråd, opsparet gennem århundreder. Dog er ikke alle ordklasser lige rigt repræsenteret.

Adverbier er således en mangelvare på arabisk. De modificerende småord som: så, vel, nok, vist, jo, dog osv. findes slet ikke, men kan ligge implicit i verbalets modalitet.

I Slægtninges kød findes en næsten enslydende replik to gange, sagt af John på s. 83 nederst og af Qabil på s. 85 nederst: 'Det passer sig for os, at vi vender hjem.' Det upersonlige verbal 'det passer sig' er udtrykt ved to forskellige, men overvejende synonyme arabiske ord, og jeg har lagt personernes sindsstemning ind i oversættelsen. John siger: "Vi bør nok vende hjem" (John har begået en tjenesteforseelse ved at lægge beslag på hærens helikopter til privat brug og har dårlig samvittighed). Qabil siger: "Vi må hellere vende hjem" (Qabil er ræd for en konfrontation med dyret, men endnu mere ræd for, at de andre skal opdage det, og han prøver at lyde nonchalant).

I princippet kan et hvilket som helst nomen gøres adverbielt ved at sætte det $\mathrm{i}$ akkusativ, men i praksis sker det på få undtagelser nær kun ved indefinitte nominer, hvor akkusativendelsen er synlig i en uvokaliseret tekst, og man foretrækker som 
regel at benytte en præpositionsforbindelse.

I Slægtninges kød, midt på s. 83, siger John: "Der er intet spor af dine gazeller på Hassawanabjerget”, og dernæst står der: 'Qabil svarede ham med et skuffet råb'. Dette er en typisk måde at undgå et adverbium på. Jeg har inkorporeret inquit i replikken og oversat som følger: "Men hyrderne så dem for kun et par dage siden', råbte Qabil skuffet tilbage."

Den første sætning i Slægtninges kød består af kun ét ord: al-asil, som er betegnelsen for en af dagens tider, tiden inden solnedgang, den sene eftermiddag. En komplet arabisk sætning kan bestå af ét ord, et verbal med implicit subjekt, men ikke af et nomen alene. Her har vi altså en ufuldkommen sætning, hvor noget skal underforstås. Den umiddelbare oversættelse kunne lyde: 'Det var sen eftermiddag/ sent om eftermiddagen. I horisonten kom bjergets tinde til syne ...' Men logisk passer det ikke. Helikopteren letter ved daggry og propellerer sig gennem dagens hede frem til skæbnetimen, der indtræffer sent om eftermiddagen. Jeg opfatter det ene ord på første linje, al-asil, som en slags underoverskrift (og dermed i nominativ; som sagt undgår man helst definitte tidsadverbier), som en forudgriben af handlingens gang - et virkemiddel, som forfatteren $\mathrm{i} ø$ vrigt benytter adskillige gange i romanen. En oversættelse kunne da lyde: 'Sent om eftermiddagen ...'. Eller 'Det skete sent om eftermiddagen'. Da historien er fortid i relation til samtidshandlingen, har jeg valgt: "Det var sket sent om eftermiddagen" og understreget tidsforskellen ved at lade følgende afsnit begynde med en tidsangivelse, der ikke eksisterer i forlægget: $\mathrm{Nu}$ kom bjergets tinde til syne ...

Genitivforbindelser kan volde problemer. 'Den smukke nabokones lille datters dukkevogn' ville på arabisk være struktureret som følger: 'vogn dukkes datters kones naboens den smukke den lille'. Så kringlet er det sjældent i virkeligheden, men alligevel. Sammensatte navneord findes ikke på arabisk, kun som genitivforbindelser, der desuden kan angive ejendomsforhold, materiale ('af guld') osv. I den ovenfor behandlede passage forekommer "bjergets tinde", som jeg under andre omstændigheder kunne have oversat som 'bjergtinden'. Her i teksten står der imidlertid et par linjer nedenunder: 'Det er den eneste bjergagtige tinde ...', hvilket jeg her oversætter: "Det er den eneste bjergtinde..." Jeg forstår således 'bjergets tinde' som 'toppen af bjerget' (resten af bjerget skjult i horisonten; i flade ørkenstrækninger fornemmes jordens runding) og respekterer de forskellige konstruktioner ved kun at benytte det sammensatte ord anden gang.

I Slægtninges kød, s. 83 nederst, står der ordret: 'De landede ved bjergets fod. De søgte efter et tilflugtssted til at beskytte sig mod solens ondskab. De skyggefulde huler er højt oppe, på bjergets øverster. Vejen til dem passerer igennem glatte klipper og andre, vildsomme og væbnet med sten som vilddyrhjørnetænder'. Passagen rummer fire genitivforbindelser, som man er nødt til at behandle forskelligt. 1: "foden af bjerget" forekommer mig lettere end 'bjergets fod'. 2: Jeg har valgt "den ondskabsfulde sol" i stedet for 'solens ondskab'; en genitivforbindelse (solens ondskab) foretrækkes ofte på arabisk frem for et substantiv med attributivt adjektiv (den onde sol). 3: 'bjergets øverster' må af indlysende grunde omformes, så sætningen f.eks. kan lyde: 'De skyggefulde huler er højt oppe på bjerget', hvor øverster betragtes som 
redundant og udelades. 4: Nominet 'vilddyrhjørnetænder' er for sammensat til at være behageligt. 'hjørnetænder på vilddyr' er ikke meget bedre. Jeg foreslår: "som hugtænder i gabet på vilddyr."

Finitte verber på arabisk efterlader en arm oversætter dinglende mellem himmel og jord. Der findes ikke tempus på arabisk, kun aspekt (fortrinsvis; tidsdimensionen kan dog undertiden angives ved partikler). Et finit verbum kan stå i perfektum og angive en afsluttet handling eller i imperfektum og angive en uafsluttet handling - foruden visse anormaliteter, såsom at en negeret, afsluttet handling står i imperfektiv, hvilket man i sine unge studieår tænderskærende lærte at tage som et fait accompli.

Øverst på s. 84 i Slægtninges kød møder Qabil sin fostersøster. Ordret oversat: 'I det øjeblik så han hende. Hun står i skyggen af en stor klippe ... Hendes øjne er store, sorte og kløgtige. De taler i et ukendt sprog; fortæller ham et eller andet; betror ham en eller anden hemmelighed ...' osv., hele sekvensen i imperfektum. Skiftet fra perfektum til imperfektum (afgjort ikke at sammenligne med historisk præsens) kan forklares med, at hovedhandlingen er afsluttet ('så han hende'), og at den følgende passage beskriver indholdet af verbet 'se' som en slags underordning ( = 'så han hende stå i skyggen af en stor klippe' - men denne konstruktion lader sig ikke gennemføre på dansk). Derudover kan skiftet signalere et billede på nethinden af en episode, der aldrig bliver glemt.

Som kronen på værket slutter passagen med en forfatterkommentar, et evigtgyldigt udsagn, der nødvendigvis må være i imperfektum: "Det hårdeste, det mest ulykkelige i livet, er at ane hemmeligheden uden at kunne fatte den." Og nej, denne aforismelignende sentens kan ikke være fostret af Qabils hjerne; Qabil er hundrede procent materialist og ikke tilbøjelig til at filosofere.

Endnu et eksempel. På s. 82 i Slægtninges kød står der ordret: 'Den legendariske græshoppe kredsede ... I det øde lands uvejsomme område står lotustræ og akacie og gyvel spredt. De vokser langt fra hinanden på sletterne, men kan trænges i visse wadier, som har nydt godt af oversvømmelserne for nylig. Ligeledes kommer noget græs til syne, klyngende sig til de fra højdedragene nedgående, udtørrede vandløb. Græsset er stadig grønt på nogle steder. Græsset i de nedgående er mest af krav på det fra højdedragene strømmende vand.' Tilsyneladende har vi her en konstruktion magen til den foregående, med hovedverbet i perfektum og den følgende beskrivelse i imperfektum. Men det skulle betyde, at de fire jægere observerer naturen og grunder over den ulige fordeling af naturens goder. Det gør de ikke; de har kun øje for jagtbytte. Skiftet fra perfektum til imperfektum kan med lidt god vilje forklares som en såkaldt hal-konstruktion, en tilstand underordnet hovedsætningen, dog uden nogen indikation derpå ('græshoppen kredsede..., mens/idet der stod lotustræ... og voksede langt fra hinanden... osv'). Mere sandsynligt er det, at skiftet af aspekt skyldes fortællerens indgriben; han beskriver den natur, som hans personer burde se. Den sidste sætning med personificering af naturen er tydeligvis en forfatterkommentar. 


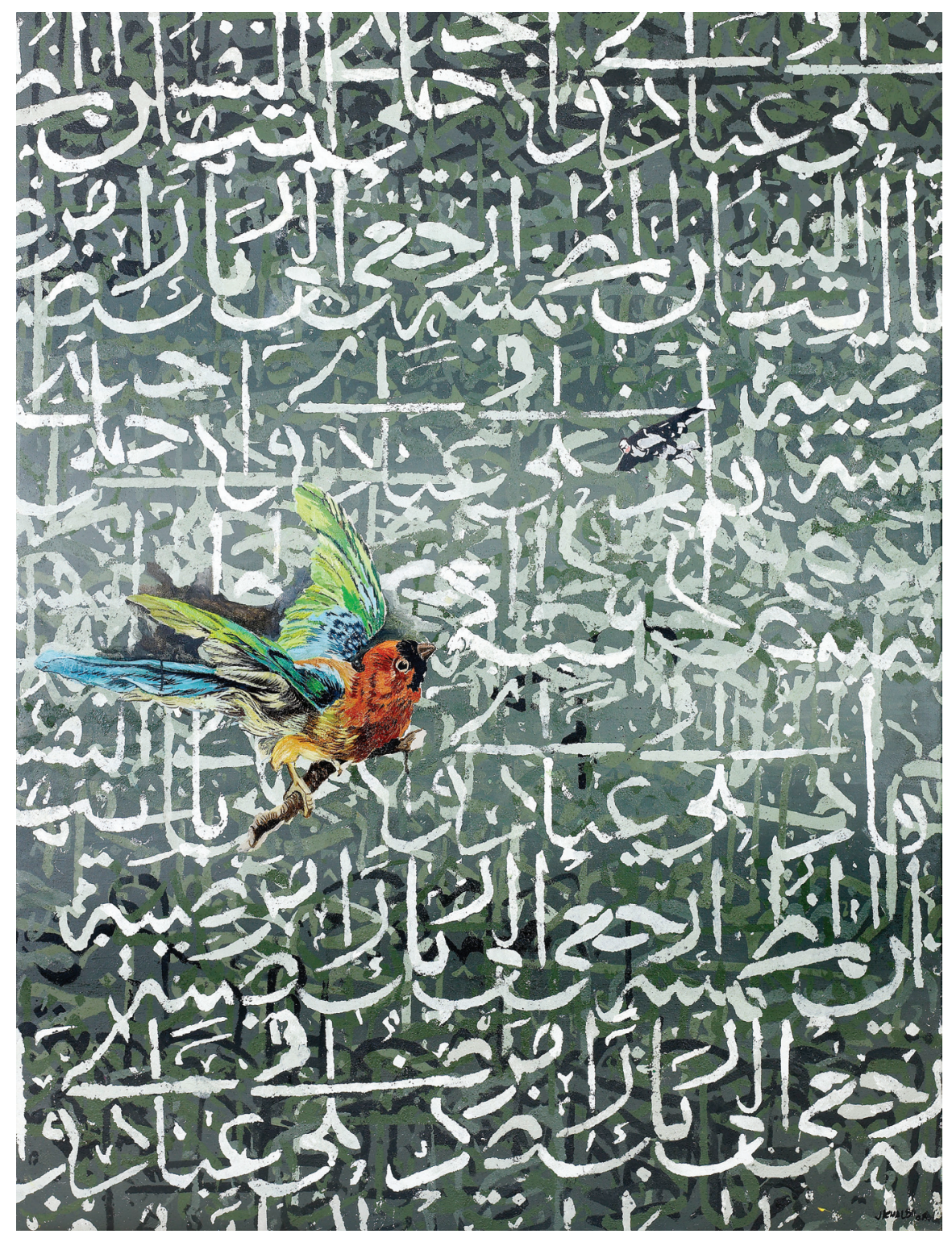

Jeffar Khaldi: Convenient Vehicle to Make a Point. Olie på lærred, 190 x 150 cm, 2008. (c) Jeffar Khaldi. Courtesy of B21 Gallery. 
Et sidste eksempel, Slægtninges kød, s. 83 nederst, citeret ovenfor i anden sammenhæng: 'De landede ved bjergets fod. De ledte efter et tilflugtssted ... De skyggefulde huler er højt oppe ... Vejen til dem passerer igennem glatte klipper ... Mellem stenene klynger sig vildtvoksende, stædigt græs, omgivet af spredte sandtunger. På det bløde sand tegnede sig slangers og firbens og gekkoers og ørkenrotters spor.' Tilsyneladende har vi her en gentagelse af de første to eksempler: Hovedhandlingen i perfektum, 'de landede', 'de ledte', og den efterfølgende beskrivelse i imperfektum. Men NB: I sidste sætning forekommer et skift tilbage til perfektum. Her er vi fra fortællerbeskrivelsen ført tilbage til handlingen: Qabil ser sporene (og intet andet), fordi han leder efter behovstilfredsstillelse og er blind for alt andet.

Essensen af disse eksempler er at forklare, hvor opmærksom man må være på grammatiske detaljer, og hvor vanskeligt det kan være at formidle de skjulte nuancer. Og det må tilføjes, at jeg ikke kunne benytte disse eksempler til en almen beskrivelse af brugen af aspekt. Eksemplerne er specifikke, et individuelt stilistisk træk, der kun kan tilskrives al-Koni. Hver forfatter har sin måde at udnytte sproget på.

Jeg har været inde på det tidligere: Arabisk er sig selv fra tidernes morgen, men har desuden suget til sig fra de tilgrænsende kulturer gennem århundreder og gør det stadig. Arabisk sprog har et enormt ordforråd. Og arabisk er jo ikke et sprog, der er forbeholdt en enkelt nation. Min libyske nomadeforfatter omtaler således den ørken, som jeg ignorant kun kender ét ord for, på en halv snes forskellige måder, sammenligneligt med grønlændernes differentierede måde at omtale sne på. Jeg har efter bedste evne fors $\varnothing$ gt at navigere mellem udtryk som ørken, øde, ødemark, åbne vidder osv. og ved, at jeg er kommet til kort. Det danske sprog er ikke rummeligt nok.

Her bør jeg vel - selvom problemet er fælles for oversættere fra alle sprog også nævne de lokale plantevækster, som jeg er ganske usikker på. På første side i Slægtninges kød er der nævnt tre slags træer/buske, sidr, talh og ratam. Ordbøgerne er gavmilde: Sidr kan betyde en slags kristtorn. Eller et lotustræ. Talh kan betyde en slags akacie. Eller et banantræ/en bananpalme. Ratam kan betyde et retemtræ. Eller en slags gyvel. Sic. Jeg valgte lotustræ, fordi jeg ikke tror på kristtorn i ørkenen. Jeg valgte akacie, fordi jeg ikke tror på bananpalmer i ørkenen. Og jeg valgte gyvel, fordi jeg ikke kender et retemtræ.

Og dyrelivet. Jeg kendte sådan set ikke på forhånd en muflon. Ifølge encyklopædien er en muflon slet ikke en ged, men en slags får; og kan får og geder parre sig med hinanden?

Et sted i romanen (uden for de to trykte tekster) beskrives Hamadasletten, som den ser ud efter år med hyppige regnskyl, hvor dyrelivet trives. Der står ordret: 'Sletterne grønnes om foråret, og så bliver der mange trøfler og fugle og harer og gazeller'. Det er ordet tirfas, trøfler, der skiller sig ud. Jeg har søgt højt og lavt i håb om, at ordet kunne bruges om et eller andet dyr, et ørkenpindsvin f.eks., men det kan det tilsyneladende ikke. Dog måske alligevel, helt lokalt, men det har jeg ingen mulighed for at verificere. Så det måtte blive 'trøfler' - og jeg tror på det, fordi al-Koni i en af sine andre romaner beskriver en person, der er forfalden 
til tirfas, beskrevet i alle detaljer. Jeg delte derfor opremsningen op for at markere forskellen mellem flora og fauna: "Om foråret blev sletterne grønne, med masser af trøfler, og der var mængder af fugle, harer og gazeller." Problemet her er konjugationen 'og', der både kan fungere som konjugation og komma; tegnsætning er en innovation i arabisk skriftsprog.

Det kan være vanskeligt at finde ækvivalenter for nominet, men dér kan man i det mindste fastholde problemet og enten løse det eller give op. Det arabiske verbum er mere uhåndgribeligt. Der findes kun to aspekter, perfektum og imperfektum - og det kan umiddelbart opfattes som en lettelse, sammenlignet med de indoeuropæiske sprogs nuancerede tempussystemer, men er det ikke for en oversætter! - og desuden fire modi: indikativ, subjunktiv, jussiv og imperativ. Til gengæld kan et verbums grundform skifte betydning ved hjælp af præfikser og infikser, og det er langtfra entydigt, hvad den nye betydning er; ordbogen kan give flere spalter at vælge imellem. Verbets grundform er form et, og derudover findes der ni ganske almindeligt brugte, afledte former, foruden yderligere fem, der er sjældne. Form to kan således bl.a. angive en intensivering af grundhandlingen, men også gøre grundhandlingen kausativ, f.eks. af verbet at løbe: at løbe energisk eller at få nogen/noget til at løbe. Hertil kommer, at verbet altid ændrer betydning i overensstemmelse med den præposition, der følger efter, hvilket antagelig ligger til grund for myten om den fortvivlede arabist, der hævdede, at det arabiske verbum har fire basale betydningsindhold: Dets grundbetydning; det modsatte heraf; noget med kameler; noget med sex.

På trods af det arabiske sprogs ordrigdom og elasticitet ejer det danske sprog også visse nuancer, som ikke findes på arabisk. Arabisk har et ord for at smile, et ord for at le og et ord for at brøle af latter. Men ikke et ord for at grine. Ifølge ovenstående havde det været nærliggende at konstruere en form to med betydningen at le meget, højt, intensivt. Det er ikke sket. Form to er udelukkende kausativ: at få til at le. Verbet $d a$ hika rummer i sin grundform begge betydninger: to laugh; to jeer, scoff, jibe, deride, ridicule, mock, scorn.

I Fra asken og i ilden bliver protagonisten Asuf tvangsrekrutteret, og da han ankommer til militærlejren, hoverer de allerede indrullerede unge mænd over endnu et offer. De griner. Asuf fortæller sin historie, og en af de unge mænd ler usikkert, da han fatter skæbnens ironi. Han fyrer sit mundheld af, og hele banden griner; for der er jo ikke noget at le ad, og slet ikke noget at grine ad. Og så griner man. Her har jeg ladet situationen bestemme.

Andre steder er det personkarakteristikken, der afgør ordvalget. Asuf er enfoldig og ren af hjerte; han ler. Hans modbillede, Qabil, ædes op indefra af sin egen grådighed og rummer ingen glæde; han griner. Ligeledes Masud, der er hans medløber og i $\emptyset$ vrigt kun spiller en mindre rolle i romanen. John er mere sammensat. Han befinder sig uddannelsesmæssigt og socialt på et højere stade end de andre, og desuden er han vesterlænding. Når han spiller kammerat med Qabil og Masud, griner han, men når han pointerer afstanden til dem, ler han. Altså må valget her være situationsbestemt. 
Slemt nok hertil. Men syntaksen er nok den instans, det er sværest at danse med. Arabisk er et semitisk sprog, og semitiske sprog er primært bygget op på hovedsætninger, forbundet med sideordnende konjugationer som 'og' eller 'så'. Især i ældre tekster kræver det fantasi og mod at bryde den fortløbende tekst op i sammenhængende sekvenser og præstere en flydende fordanskning. En klassisk dannet forfatter som Naguib Mahfuz kan, især i sine tidlige værker, begå en halv side med lutter sideordninger, uden en pause.

I min nuværende oversættelsesopgave er jeg syntaktisk heldig: Ibrahim al-Koni er ganske vist klassisk dannet; men med tuaregisk som modersmål er arabisk kun hans andet sprog og derfor mindre indgroet. Desuden har han modtaget sin højere uddannelse i Moskva, skrevet sine første noveller på russisk, læst verdenslitteraturen, specielt den russiske og med særlig forkærlighed for Turgenjev og Dostojevski, på originalsprogene. al-Koni er syntaktisk ikke noget skræmmebillede.

Alligevel skriver han jo på litterært arabisk og følger skriftsprogets regler. I Slægtninges $k \varnothing d$, s. 83 nederst og allerede citeret flere gange, står der: 'De landede ved bjergets fod. De søgte efter et tilflugtssted ... De skyggefulde huler er højt oppe ... Vejen til dem passerer igennem ...' Her har vi en klassisk arabisk sideordning, blot med den moderne forfatters punktum i stedet for 'og'. Jeg har samlet de fire hovedsætninger i grupper på to og to, hver forbundet med konjugationen 'og', og desuden ignoreret et linjebrud efter første sætning: "De landede ved foden af bjerget og gav sig til at lede efter et sted, hvor de kunne finde ly mod den ondskabsfulde sol. De skyggefulde huler lå højt oppe på bjerget, og vejen derop gik over glatte klipper ..."

Den indkapslede sætning med et finit verbum spiller på arabisk en mindre rolle end på dansk, og verbaladjektiver og verbalnominer bliver ofte benyttet, hvor det danske sprog kræver adjektiviske og adverbielle ledsætninger. Da kancellistil ikke er acceptabelt i oversættelsen af en moderne arabisk roman, og da man ikke er engelsksproget og kan benytte sig af de smidige -ingformer, og for så vidt også passiv participium, må den arabiske teksts struktur omformes.

Således står der i Fra asken og i ilden, første linje: 'Kaptajn Bordellos mænd arresterede ham på den første dag for hans indgåen i oasen.' Her må verbalnominet omformes til en ledsætning i den danske oversættelse.

I Slægtninges $k \varnothing d$, andet afsnit: 'Med dagens fremskriden og solens bliven arrogant blegner...' Denne konstruktion er vanskeligere, fordi den er sammensat, og fordi den kræver kendskab til forfatterens billedsprog. Solen er den altdominerende faktor i ørkenen, den nådesløse tyran, der brænder/lutrer alt levende, men som lykkeligvis detroniseres og ydmygt knæler ind under aften, hvorved alt levende i ørkenen får et pusterum, og den svækkede tyran vinder nye kræfter til morgendagens fornyede herskervælde. Jeg har oversat passagen som to sideordnede tidsbisætninger: "Når dagen skrider frem, og solen hovmodigt tager magten."

Verbaladjektiver kan erstatte den relative bisætning, f.eks. i Fra asken og i ilden, andet afsnit: 'Her fandt han en flok unge, i garnisonen internerede mænd.' Der står ikke: 'Her fandt han en flok unge, internerede mænd i garnisonen'; så der er ikke andet for end at gribe til den tungere relativ-konstruktion. 
I Slægtninges kød, s. 83 øverst, finder vi et lignende eksempel: 'Den tynde tråd på jordens hårde af sorte sten dækkede krop førte til Hassawanabjerget.' Det må igen blive en relativ bisætning: "Den tynde tråd hen over jordens hårde legeme, der var dækket af sorte sten, førte..." Når participier defineres på en eller anden måde, råder nudansk kun over ledsætning med finit verbum.

En halv snes linjer længere nede i samme tekst finder vi: 'Den flyvende græshoppe drejede, tegnende en vid cirkel.' 'Flyvende' lægger sig attributivt til 'græshoppe (begge determinerede), mens 'tegnende' er indetermineret, svarende til en engelsk aktiv participium, noget i retning af: 'Den flyvende græshoppe drejede, tegnende/idet den tegnede en vid cirkel.' Jeg har i min oversættelse valgt en forholdsordsforbindelse, med udeladelse af verbet 'at tegne': "Den flyvende græshoppe drejede rundt i en stor cirkelbevægelse."

Man kan være enig eller uenig i de valg, jeg har truffet; selv er jeg ofte uenig, tvivlrådig. Havde det alligevel i overstående eksempel været bedre med: 'Den flyvende græshoppe beskrev en vid cirkel, da den vendte om'? Men alle kan ud fra de givne eksempler være enige om, at der skal træffes et valg, hele tiden; og at en fordanskning uvægerligt må omforme og nedtone den arabiske grundtekst. Arabisk er et semitisk sprog og ligger som sådant temmelig fjernt fra de kendte, indoeuropæiske strukturer.

\section{Kultur}

Grænsen mellem sprog og kultur er naturligvis fiktiv. Sproget er, som det er, på grund af kulturen; eller kulturen er, som den er, på grund af sproget. Når jeg har valgt at dele stoffet op i sprog og kultur, er det udelukkende af selvdisciplinære grunde. Der er ingen faste grænser mellem de to områder, hvilket allerede er bevist, for jeg har under sprogdelen ikke kunnet undgå at berøre kulturdelen, og jeg vil heller ikke kunne undgå at berøre sprogdelen under kulturdelen.

Og så må jeg lige definere, hvad jeg i denne sammenhæng mener med kultur. Ikke noget med kogekar, bryllupsceremonier, amuletter og islam. Med kultur mener jeg sprogkultur. Hvad anses for god og smuk sprogbrug på arabisk, og hvordan divergerer denne opfattelse fra den vesterlandske?

Ud fra det meget lille tekstmateriale, jeg har til min rådighed, vil jeg prøve kort at belyse et udvalg af kulturelt bestemte, æstetisk fremmedartede forhold.

Undertiden har den arabiske tekst 'for meget' med. Arabisk er et kropsligt sprog, der med forkærlighed inddrager så mange dele af den menneskelige fysik som overhovedet muligt: Man stamper med foden, griber med hånden, lugter med næsen, bider med tænderne. Heftige følelser, såsom erotisk lidenskab, vrede eller rædsel, kan involvere hele det indre menneske, indvolde, blodårer, nervebaner og tarmkanal. Mere, end det vestlige sind kan rumme. Stik imod hensigten kommer en sådan beskrivelse let til at virke komisk. Hvordan skal en oversætter forholde sig hertil? Vil man 'oversætte' en ægtefølt kærlighed, sorg eller desperation, må man vel beskære indvoldene kraftigt - og dermed øve vold mod forlægget.

Ibrahim al-Koni er som sagt vestliggjort og heller ikke i denne sammenhæng nogen stor synder. Jeg har i de to tekstbilag kun fundet et enkelt eksempel, Fra asken 
og i ilden, første side: 'Har I set et menneske undslippe italienernes kugler, mens han løber på sine ben/fødder, indtil han har skjult sig i bjergenes mørker?' Hvad skulle nogen/noget løbe på, om ikke sine egne ben/fødder? Jeg har oversat sætningen: "Har I før set et menneske undslippe italienernes kugler og galoppere af sted for at forsvinde i de mørke bjerge?"

I slutningen af romanen bliver Qabil vanvittig (teksten er ikke optrykt i Passage), og dér kan al-Koni ikke nære sig. Jeg har haft svære problemer med, at hans øjne dels synker ind i øjenhulerne, dels popper frem i galskab; med hans savl, der drypper i tynde tråde, ligesom hans offers blod, der i tråde flyder ned over en stentavle. Men hos al-Koni er de fysiske udladninger i det mindste usentimentale, selvom de er heftige.

Billedsproget i arabisk litteratur har aner tilbage til djahiliyya-tiden (uvidenhedens tid), tiden inden Muhammad og islam. Der er således i Slægtninges kød, s. 83 øverst, et smukt eksempel på, at en veksel eller en karavanevej gennem terrænet beskrives som en flænge/et sår i et legeme, og dette billede kan føres tilbage til det femte århundrede: "Qabil kiggede ned gennem vinduet i græshoppen og udpegede i den mørke, askegrå jordoverflade en flænge, der var ved at hele." Forskellen på det femte århundredes sammenligning og nutidens er, at dengang var billedet rent deskriptivt, mens det nu, hos al-Koni, er værdiladet og miljøpolitisk. At der er tale om dyrenes spor, fremgår ikke af metaforen (men ganske vist ved Qabils efterfølgende replik), og personificeringen (jorden som et menneskeligt legeme) må man foreløbig gætte sig til (den forklares et par linjer længere nede i teksten - al-Koni er klar over, at ikke alle hans læsere, end ikke alle hans arabisksprogede læsere, er fortrolige med præislamisk poesi). Fællesmængden for de to sammenligningsled må man også gætte sig til, antagelig, at linjen er lige og tynd, som skåret med en skarp kniv i et rent snit. Endvidere er metaforen dynamisk. Der er en proces i gang, for flængen er ved at hele; sporet er altså delvis udvisket, antagelig af blæsten og støvet og sandet, og man forestiller sig, at det om kort tid vil være helt borte, uden at efterlade ar.

I Slægtninges kød, s. 83 nederst, citeret ovenfor i en anden sammenhæng, finder vi en blandet sammenligning og metafor: De vildsomme klipper er 'væbnet med sten som vilddyrhjørnetænder.' Der er en sammenligningspartikel 'som' (på arabisk en præposition), og både første og andet sammenligningsled er nævnt. Jeg har ladet fællesmængden komme eksplicit til udtryk i min oversættelse: "væbnet med sten så skarpe som hugtænder i gabet på vilddyr". Derudover er klipperne implicit beskrevet som væbnede krigere (igen en personificering), der forsvarer sig mod de påtrængende fremmede med deres lanser (sten), der er spidse, skarpe og dødbringende som rovdyrtænder.

Et sidste eksempel på billedsprog, i Slægtninges kød, midt på s. 83: 'Fatamorganaets floder strømmede og truede med bjergets fødders bortskylning', i min oversættelse: "Strømme af luftspejlinger vældede frem og truede med at skylle fødderne væk under bjerget." Fatamorganaet sammenlignes med vand, hvilket er et meget almindeligt billede. Det ualmindelige består i, at sammenligningen strækkes til det absurde, således at det imaginære vand får magt til at flytte bjerge. Billedet skal 
opfattes på to måder, helt bogstaveligt og deskriptivt: Bjerget ser ud, som om det svømmer i vand; og desuden i overført betydning: Benene er ved at blive slået væk under det. Både fatamorganaet, der truer, og bjerget, der har fødder, personificeres, og billedet refererer til et gennemgående tema i romanen, en myte om ørkenens skabelse, om bjergørkenen og sandørkenen, der bekrigede hinanden og først blev pacificeret, da guderne sendte mennesket ned i wadien som en fjende af dem begge. Her ser det ud til, at fjendtlighederne er blusset op igen, og at sandørkenen med sine luftspejlinger har overtaget. Jeg er stadig i tvivl om oversættelsen. Ovenfor har jeg gennemført vand-billedet: strømme, vældede frem, skylle væk. Verbet djarafa kan betyde at feje væk, at skylle væk; ikke at slå væk. Men når vi nu har et lignende udtryk på dansk ... Og desuden synes jeg, at den arabiske teksts underfundige lune formidles bedre ved 'slå fødderne væk under'.

Da jeg oversatte min første roman, var jeg usikker - og det er jeg såmænd stadig, for man bliver indfanget af den arabiske tekst, af sprog og billedsprog, og blind over for sit eget sprog. Jeg bad derfor en god ven og magister i dansk om at læse min oversættelse igennem og påpege iøjnespringende arabismer. ${ }^{3}$ En af de ting, han slog ned på, var billedsproget: Det var blandede metaforer, det var ét virvar, det var sort tale. Enten kunne jeg ikke oversætte, eller også kunne Naguib Mahfuz ikke skrive! Vi skændtes. Men enedes vist nok om et kompromis. Sagen er den, at arabisk æstetik adskiller sig fra Vestens forestillinger om enkelhed, klarhed og skønhed. Jo mere blandet den arabiske metafor er, jo flere facetter af den sammenlignede genstand der belyses, jo mere af den omgivende verden der inddrages i sammenligningen, jo skønnere og rigere anses billedet for at være. Billedet skal være vanskeligt at fastholde, dirrende, mystisk, således at læseren ruskes ud af sin søvnige passivitet og begynder at tænke, afprøver forskellige muligheder - måske også nogle, som aldrig er faldet forfatteren ind - og dermed får udvidet sit syn på livet og verden. Billedet skal naturligvis være elegant formuleret og mangfoldigheden udtrykt med så få ord som muligt. Et entydigt og stillestående billede regnes for fantasiløst.

Klassisk arabisk litterær kritik ville have givet Ibrahim al-Koni en pæn anmeldelse for hans billedsprog.

Bemærk f.eks. billedet i Slægtninges kød, midt på s. 82. Morgendisen må vi gætte os til og tro på, at den op ad dagen afspejler himlens blå farve, for først helt at forsvinde over middag. Bjerget ligner et menneske, nærmere bestemt en tuareg. Tuaregerne kaldes Det Blå Folk, fordi mændene bærer blå turban og skjuler nederste del af ansigtet bag et blåt klæde, som kaldes et slør eller en maske. Igen strejfer forfatteren i billedsproget et hovedtema i bogen - ja, i hele forfatterskabet: Området er tuaregernes land; natur og nomade hører sammen.

Bemærk ligeledes i samme tekst, s. $83 \varnothing$ verst, beskrivelsen af palmetræerne. Vi må gætte os til, at det blæser: Træerne er i bevægelse, puffer til hinanden, og vindens susen i kronerne lyder som hvisken. Træerne, der er sorte i silhuet mod sandet, ligner de sorte troldmænd fra Timbuktu, der er navnkundige for deres amuletter og trylleformularer.

Min gode ven blev for tredive år siden irriteret over arabisk billedsprog, og for nylig læste jeg en anmeldelse af den somaliske forfatter Nuruddin Farahs netop for- 
danskede bog, Forbindelser. ${ }^{4}$ Anmelderen gav den dumpekarakter, bl.a. fordi billedsproget var sært, kluntet, bagvendt. Anderledes. Vesterlændinge har svært ved at acceptere, at der findes andre værdinormer end de vesterlandske, irriteres over anderledesheden og forkaster i mange tilfælde det anderledes. Det er synd, både for os selv og for det anderledes.

Den sidste kulturbestemte vanskelighed, jeg vil komme ind på, er oversættelse af ordsprog. Visdomslitteraturen udgør sin egen genre inden for klassisk arabisk litteratur, og ved siden af lever mundheldene deres eget liv i alle arabisktalende områder, som gennem generationer mundtligt overleveret folkeeje. Forfatteren til den anden roman, jeg har oversat, Emily Nasrallah, fortalte mig engang, da jeg besøgte hende i Libanon, og som svar på min klage over hendes mange uoversættelige ordsprog, at man i hendes fødelandsby kunne føre hele samtaler, der udelukkende bestod af ordsprog: I landsbyen sker der intet nyt, alle ord er for længst udtalt, al visdom akkumuleret gennem generationer; så hvorfor ikke holde sig til den eksisterende visdom ${ }^{5}$ Hun kunne naturligvis ikke hjælpe mig med oversættelsen, kun forklare mig nogenlunde, hvad ordsprogene betød. Ordsprog er uomgængelige i arabisk prosa.

Qabil prøver et sted i romanen at få John til at stille en helikopter til rådighed med henblik på en jagtudflugt, og John protesterer, fordi det egentlig er forbudt. Så siger Qabil (uden for det trykte tekstmateriale): 'Den, der elsker/holder af roser, må finde sig i deres torne. Kender du det ordsprog?' Tilsyneladende såre simpelt, for der findes et lignende ordsprog på dansk: Ingen roser uden torne. Det går bare ikke, for i det følgende bruger John ordsproget til at hudflette Qabil i en svada, der ender med, at Qabil ikke elsker/holder af noget eller nogen, bortset fra sig selv. Jeg kan altså ikke komme uden om verbalet 'elsker/holder af'. I dette tilfælde har jeg både gengivet det tilsvarende danske ordsprog og dets arabiske ordlyd: "Kender du ordsproget: Ingen roser uden torne? Den, der holder af roser, må også finde sig i tornene."

I Fra asken og i ilden, midt på s. 81, forekommer der et ordsprog, der har givet mig grå hår i hovedet, og som jeg ikke kan slippe. Det er ekstra højlydt, fordi det har givet navn og overskrift til kapitlet. Replikken, hvori det findes, lyder: 'Dette er noget, hvorom man kan sige: Sovende af vind kaster knoglerne i tarmene.' Jeg har ikke kunnet finde dette ordsprog i noget opslagsværk. Meningen er ud fra romanens kontekst for så vidt tydelig nok. Personen, Asuf, går fra slemt til værre, og vi har på dansk et udtryk, der dækker meningen fortrinligt: At komme fra asken og i ilden. Den danske talemåde er i denne sammenhæng perfekt, næsten lidt for perfekt. Tørken har lagt Asufs liv i aske; tørken har svedet alt planteliv bort, så hans geder er døde og han selv halvdød af sult; tørken har tvunget ham til at søge ned til oaserne, hvor man fluks lægger ham i lænker med henblik på at sende ham i krig, i ilden.

Men med dette danske udtryk forsvinder det oprindelige billede i den arabiske tekst helt. 'Sovende/hvilende/løjende af af vind' - det sidste betydningsindhold kommer nærmest, da vinden eksplicit er nævnt, noget med at ligge vindstille. Ghat ligger ganske vist meget langt inde i landet, og lokalbefolkningen har aldrig set havet, endsige sejlet på det. Men den unge mand, der siger replikken, kan jo være kom- 
met med en karavane fra Libyens kyst og kende til sømandsliv. Ordsproget kunne så betyde: Den, der ikke har vind i sejlene, griber til at æde knogler (hvilket stiller den øjeblikkelige sult, men siden giver en gevaldig mavepine). Evt: 'Hvilende af vind vinder ben i bug'. Eller 'Mand af vanheld kaster knogler i vom'. Fine, fine hjemmestrikkede ordsprog. Men hvem i danernes rige kan vel forstå dem? Jeg holder mig nok alligevel til asken og ilden.

Det har været en trælsom vandring gennem sproglige finurligheder, og jeg er enhver, der er nået så langt som hertil, tak skyldig. Jeg håber at have givet et indtryk af, hvor langt der er imellem indoeuropæiske og semitiske sprog, imellem dansk og arabisk kultur; hvor stor en rolle, tilfældighederne spiller, og hvor heftigt fortolkende enhver oversættelse nødvendigvis må blive.

Oversættelse fra arabisk til dansk kan kun blive tilnærmelse; men selv det er vel ikke at foragte. Det kan være øjenåbnende og helsebringende at anskue verden fra en anderledes synsvinkel.

\section{Noter}

I Ibrahim al Koni: Blod af Sten. Oversat af Ellen Wulff. Forlaget Vandkunsten, 2009.

2 Wadi: Et udtørret flodleje; frugtbart, fordi regnen fra fjerne bjerge ledes ned igennem det; en dødsfælde, fordi ingen ved, hvornår det regner i de fjerne bjerge og derfor ikke kan bringe sig selv og det græssende kvæg i sikkerhed, inden den rivende strøm skyller alt bort.

3 Naguib Mahfouz: Tyven og hundene. Oversat af Ellen Wulff. Forlaget Tiden, 1990.

4 Nuruddin Farah: Forbindelser. Oversat af Karsten Sand Iversen. Athene, 2009.

5 Emily Nasrallah: Rejse mod tiden. Oversat af Ellen Wulff. Fremad, 1993. 